\title{
Potential Role of Edetate Disodium-Based Therapy in the Treatment of Atherosclerosis in Patients with Diabetes
}

\author{
Zenith H Alam D0 ${ }^{1}$, Francisco Ujueta MD $^{1}$ and Gervasio A Lamas MD ${ }^{1,2 *}$ \\ ${ }^{1}$ Department of Medicine, Mount Sinai Medical Center, USA \\ ${ }^{2}$ Columbia University Division of Cardiology, Mount Sinai Medical Center, USA
}

Submission: June 17, 2019; Published: July 09, 2019

*Corresponding author: Gervasio A Lamas, Columbia University Division of Cardiology, Mount Sinai Medical Center, 4300 Alton Road, Suite \# 2070A, Miami Beach, FL 33140, USA

Keywords: Diabetes; Atherosclerosis; Revascularization techniques; Medical therapy; Vascular health; Coronary artery disease; Peripheral artery disease; Hypertension; Inflammation; Urine cadmium levels; Critical limb ischemia; Obesity

Abbreviation: CAD: Coronary Artery Disease; MI: Myocardial Infarction; PAD: Peripheral Artery Disease; ATSDR: Agency for Toxic Substances and Disease Registry; CLI: Critical Limb Ischemia; TACT: Trial to Assess Chelation Therapy

\section{Introduction}

In 2017, 30.3 million patients had diabetes in the United States (9.4\% of the US population.) An additional 7.2 million have undiagnosed diabetes [1]. Diabetes is the seventh leading cause of death in the United States [2], and increases the risk of coronary artery disease (CAD). As such, diabetes contributes to the complications of CAD, including myocardial infarction (MI), revascularization, and death. Diabetes also contributes to the risk of lower extremity vascular disease and associated procedures, including amputation [3,4]. Although revascularization techniques and medical therapy have improved the management of atherosclerosis, there remains ample residual risk and opportunity for novel therapies, such as the one discussed here. This mini-review will explore the effect of toxic metals on vascular health and emerging benefit of therapies targeting reduction of body burden of toxic metals, particularly lead and cadmium, in patients with diabetes.

\section{Toxic Metals and Vascular Disease}

\section{Lead}

Epidemiologic studies suggest that toxic metal exposure, especially to lead, is associated with atherosclerosis, hypertension, CAD, and peripheral artery disease (PAD) [5,6]. Lead is listed as \#2 in the Agency for Toxic Substances and Disease Registry (ATSDR) Substance Priority list determined to pose the largest threat to health via toxicity and exposure potential, only second to arsenic since 1997 [7]. Lead exposure continues to be a widespread issue due to chronic contamination from soldered joints in water pipes, lead-based paints, soil contaminated with prior leaded gasoline, and airborne emissions [8,9]. Once absorbed, lead has an intravascular half-life of about a month $[10,11]$. It then moves to bone, with a half-life of about 30 years [11]. Lead substitutes for calcium in various intracellular reactions and, as such, inhibits endothelial nitric oxide synthase leading to endothelial dysfunction, oxidative stress, and in-

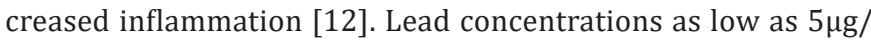
$\mathrm{dL}$ are associated with an increased risk of cardiovascular disease mortality, suggesting that there may be no "safe" lead level [5]. Urine lead after a chelation challenge with edetate disodium infusion may inform on total body metal burden.

\section{Cadmium}

Cadmium is a toxic heavy metal widely distributed in the environment and ranked as \#7 in the ATSDR Substance Priority list. Cadmium use has increased since the 1940s in conjunction with industrialization. Sources of environmental cadmium include construction, plastics processing, rechargeable batteries, and others. Cadmium makes its way into the food supply via contaminated water and fertilizer [13]. The biological half-life of cadmium varies between 17-30 years with limited excretion from the body[8]. Urine cadmium may inform on total body cadmium burden. Cadmium inhibits nitric oxide synthesis in endothelial cells and increases oxidative stress by catalyzing reactive oxidative species [14]. 


\section{Current Research in Diabetes \& Obesity Journal}

Furthermore, cadmium decreases the function of serum paraoxonase, which diminishes the antioxidant effect of highdensity lipoprotein particles [15]. Cadmium-induced adipose tissue dysfunction promotes insulin resistance, even in patients without obesity [16]. In the Strong Heart Study, elevated levels of urinary cadmium were associated with increased cardiovascular and all-cause mortality, especially in patients with diabetes [13]. Our own studies in a different, far smaller population suggested an association between cadmium level and severity of PAD in both spontaneous and post-edetate disodium infusion urine. The highest urine cadmium levels were present in patients with critical limb ischemia (CLI) [17].

Chelation of lead and cadmium: Edetate disodium has a high affinity to bind metal cations, such as cadmium and lead. Thus, a treatment regimen might have the potential to decrease total body burden of these toxic metals. Arenas et al. demonstrated that a single infusion of edetate disodium-based infusion can increase total urinary metal by $71 \%$ compared to baseline $(\mathrm{P}<0.0001)$ with the highest effects in lead $(3835 \%)$ and cadmium (633\%) [18].

Clinical benefit of edetate disodium chelation: The NIHfunded Trial to Assess Chelation Therapy (TACT) was the first well-powered randomized, double-blinded, placebo-controlled trial to assess the benefit of edetate disodium-based therapy in post-MI patients $[19,20]$. The overall study was positive[19]. In the pre-specified subgroup of patients with diabetes, however, edetate disodium-based chelation demonstrated a marked reduction in the primary endpoint (death from any cause, reinfarction, stroke, coronary revascularization, or hospitalization for angina: $\mathrm{HR}=0.59 ; 95 \% \mathrm{CI}, 0.44-0.79$; $\mathrm{P}<0.001$, Figure 1) [20]. There was a strong effect size on both recurrent myocardial infarction and death from any cause- which were significantly reduced by $52 \%$ and $43 \%$, respectively[20]. Supporting the potent biological activity of this treatment, there is emerging evidence of clinical benefit in patients with CLI and risk of amputation (Figure 2) [21,22].

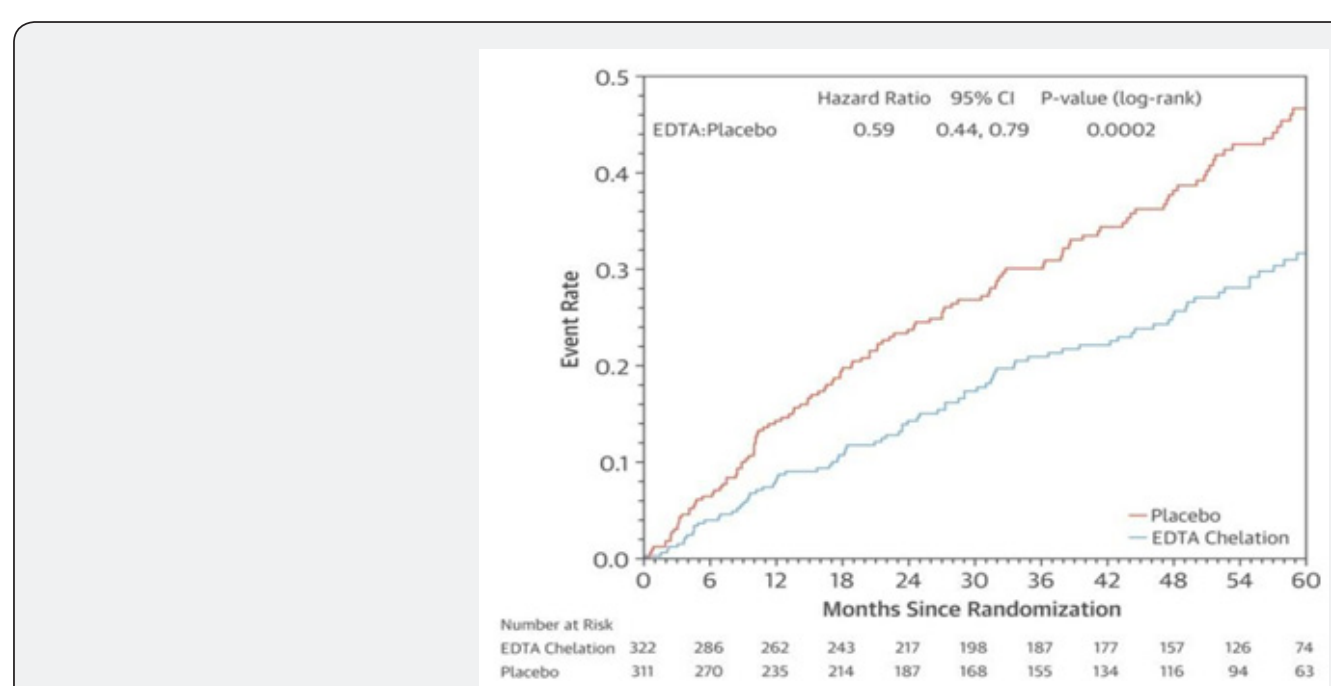

Figure 1: Primary endpoint in patients with diabetes. The primary endpoint was a composite of death of death from any cause, reinfarction stroke, coronary revascularization, or hospitalization for angina. Kaplan- Meier Estimates of the Primary Composite Endpoint EDTA Chelation Therapy vs. Placebo: Subset of Patients with Diabetes: Hx, Med Use or Baseline Glucose>=126; Cl: Confidence Interval [20].
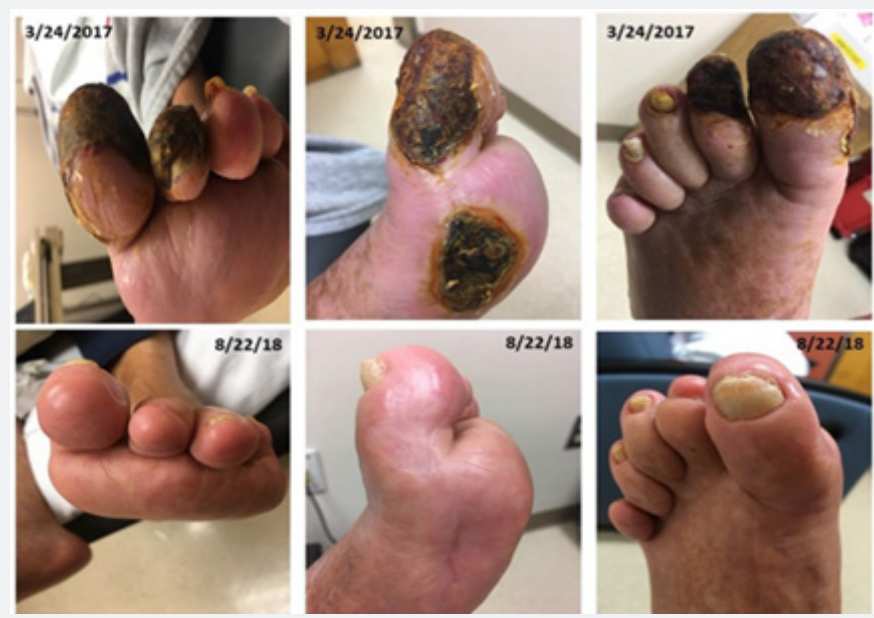

Figure 2: Patient with CLI and diabetes at baseline and after 40 infusions with edetate disodium-based chelation [21]. 
Vascular decalcification by edetate disodium - an alternative hypothesis: Edetate disodium may have the ability to directly bind and remove calcium complexes within the medial vasculature along the elastic lamellae (Mönckeberg's sclerosis), thus improving vascular compliance. Mönckeberg's sclerosis is found in patients with diabetes and renal dysfunction. As this is correlated with increased cardiovascular events and leg amputation in patients with diabetes, preliminary data based on localized nanoparticle periadventitial delivery of chelation suggest that edetate disodium could be used to reverse elastinspecific medial vascular calcification without sacrificing bone integrity or blood calcium levels [23]. Similarly, Maniscalco et al. demonstrated in a study totaling 100 patients with high coronary artery calcium scores that treatment with edetate disodium and tetracycline demonstrated a $57 \%$ significant decrease in total coronary arterial calcium $(\mathrm{P}=0.001)$ in the 77 patients completing the study [24]. Thus, as with all new therapies, there are competing hypotheses for mechanisms, all of which may be right.

\section{Conclusion}

Edetate disodium-based infusions enhance urinary excretion of toxic metals, notably lead and cadmium. We hypothesize that offloading vasculotoxic metals decreases cardiovascular events, particularly in patients with diabetes. Decalcification of small arteries and arterioles may also have a mechanistic role. Regardless of mechanism, we believe that there is a role for edetate disodium treatment of patients with a prior MI or CLI, particularly if they have diabetes. TACT2 (post-MI patients with diabetes) and TACT3a (patients with diabetes and CLI) will further explore the potential benefits of edetate disodium-based therapy in patients with diabetes and atherosclerotic disease.

\section{References}

1. (2017) Center of Disease Control. National Diabetes Statistics Report.

2. (2015) Statistics about diabetes.

3. Leon BM, Maddox TM (2015) Diabetes and cardiovascular disease: Epidemiology, biological mechanisms, treatment recommendations and future research. World J Diabetes 6(13): 1246-1258.

4. Wojtasik-Bakalarz J, Ruzsa Z, Rajowski T (2019) Impact of coronary artery disease and diabetes mellitus on the long-term follow-up in patients after retrograde recanalization of the femoropopliteal arterial region. J Diabetes Res 2019: 6036359.

5. Lanphear BP, Rauch S, Auinger P, Allen RW, Hornung RW (2018) Lowlevel lead exposure and mortality in US adults: a population-based cohort study. Lancet Public Health 3(4): e177-184.

6. Chowdhury R, Ramond A, O’Keeffe LM, Shahzad S, Kunutsor SK, et al. (2018) Environmental toxic metal contaminants and risk of cardiovascular outcomes: systematic review and meta-analysis. BMJ 362: k3310.
7. (2011) Agency for Toxic Substances and Disease Registry (ATSDR) The priority list of hazardous substances. Atlanta (GA): U. S. Department of Health of Human Services, Public Health Service.

8. Flora SJS, Mittal M, Mehta A (2008) Heavy metal induced oxidative stress. The Free Library.

9. (2019) US EPA O. Learn about lead.

10. Miller AL (1998) Dimercaptosuccinic acid (DMSA), a non-toxic, watersoluble treatment for heavy metal toxicity. Altern Med Rev 3(3): 199207.

11. Patrick L (2006) Lead toxicity, a review of the literature. Part 1: Exposure, evaluation, and treatment. Altern Med Rev 11(1): 2-22.

12. Navas-Acien A, Tellez-Plaza M, Guallar E, Muntner P, Silbergeld E, et al. (2009) Blood cadmium and lead and chronic kidney disease in US adults: a joint analysis. Am J Epidemiol 170(9): 1156-1164.

13. Tellez-Plaza M, Guallar E, Howard BV, Umans JG, Francesconi KA, et al. (2013) Cadmium exposure and incident cardiovascular disease. Epidemiology 24(3): 421-429.

14. Peguero JG, Arenas I, Lamas GA (2014) Chelation therapy and cardiovascular disease: connecting scientific silos to benefit cardiac patients. Trends Cardiovasc Med 24(6): 232-240.

15. Pollack AZ, Sjaarda L, Ahrens KA, Mumford SL, Browne RW, et al. (2014) Association of Cadmium, Lead and Mercury with Paraoxonase 1 Activity in Women. 9(3): e92152.

16. Tinkov AA, Filippini T, Ajsuvakova OP, Aaseth J, Gluhcheva YG, et al. (2017) The role of cadmium in obesity and diabetes. Sci Total Environ 601-602: 741-755.

17. Ujueta F, Arenas IA, Diaz D, Yates T, Beasley R, et al. (2018) Cadmium level and severity of peripheral artery disease in patients with coronary artery disease. Eur J Prev Cardiol.

18. Arenas IA, Navas-Acien A, Ergui I, Lamas GA (2017) Enhanced vasculotoxic metal excretion in post-myocardial infarction patients following a single edetate disodium-based infusion. Environ Res 158: 443-449.

19. Lamas GA, Goertz C, Boineau R, Mark DB, Rozema T, et al. (2013) Effect of disodium EDTA chelation regimen on cardiovascular events in patients with previous myocardial infarction: the TACT randomized trial. JAMA 309(12): 1241-1250.

20. Escolar E, Lamas GA, Mark DB, Boineau R, Goertz C, et al. (2013) The effect of an EDTA-based chelation regimen on patients with diabetes mellitus and prior myocardial infarction in the Trial to Assess Chelation Therapy (TACT). Circ Cardiovasc Qual Outcomes 7(1): 15-24.

21. Ujueta F, Arenas IA, Yates T, Beasley R, Diaz D, et al. (2019) Edetate Disodium-Based Treatment in a Patient with Diabetes and Critical Limb Ischemia After Unsuccessful Peripheral Arterial Revascularizations: A Case Report. Clinical Diabetes 2019: cd180059.

22. Arenas IA, Ujueta F, Diaz D, Navas-Acien A, Beasley R, et al. (2018) Pilot study of Edetate Disodium-based chelation in diabetics with critical limb ischemia. Circulation 138: A13005.

23. Lei Y, Grover A, Sinha A, Vyavahare N (2013) Efficacy of reversal of aortic calcification by chelating agents. Calcif Tissue Int 93(5): 426435.

24. Maniscalco BS, Taylor KA (2004) Calcification in coronary artery disease can be reversed by EDTA- tetracycline long-term chemotherapy. Pathophysiology 11(2): 95-101. 
Your next submission with Juniper Publishers will reach you the below assets

- Quality Editorial service

- Swift Peer Review

- Reprints availability

- E-prints Service

- Manuscript Podcast for convenient understanding

- Global attainment for your research

- Manuscript accessibility in different formats

( Pdf, E-pub, Full Text, Audio)

- Unceasing customer service

Track the below URL for one-step submission https://juniperpublishers.com/online-submission.php 